\title{
The Role of Emotions in Interstate Relations: Using an Interpersonal Conflict Model to Reconceptualize Pakistan's Obsession vis-à-vis India
}

\begin{tabular}{|c|l|}
\hline Journal: & Asian Journal of Comparative Politics \\
\hline Manuscript ID & ACP-19-0024.R1 \\
\hline Keywords: & $\begin{array}{l}\text { India-Pakistan, Emotions, Obsessive Rivalry, Interpersonal Conflict } \\
\text { Model, Partition }\end{array}$ \\
\hline Abstract: & $\begin{array}{l}\text { Despite using the terms such as "siblings" or "brothers from the same } \\
\text { mother" by many, there are few or no attempts to explain the wide } \\
\text { ranging sentiments associated with India-Pakistan rivalry from a } \\
\text { theoretical perspective. A cross-disciplinary approach has been employed } \\
\text { in this article to re-examine and to reconceptualize the existing } \\
\text { landscape of Pakistan-India conflict. An interpersonal conflict model has } \\
\text { been used to theorize the emotions found in their bilateral relations } \\
\text { obich have often been neglected or marginalized while studying their } \\
\text { dyad of these nation-states on diametrically opposite ethnic or religious } \\
\text { grounds, this article categorizes Pakistan and India as they are former } \\
\text { family members who parted their ways in 1947. This article explains } \\
\text { different phases of an interpersonal conflict model and clarifies how the } \\
\text { emotional climate associated with these phases could be transposed to } \\
\text { an intergroup and interstate level of conflicts between communities who } \\
\text { used to live together for centuries, and engage them in a perpetual } \\
\text { rivalry. }\end{array}$ \\
\hline
\end{tabular}

\section{SCHOLARONE \\ Manuscripts}




\title{
The Role of Emotions in Interstate Relations: Using an Interpersonal Conflict Model to Reconceptualize Pakistan's Obsession vis-à-vis India
}

\begin{abstract}
Despite using the terms such as "siblings" or "brothers from the same mother" by many, there are few or no attempts to explain the wide ranging sentiments associated with India-Pakistan rivalry from a theoretical perspective. A cross-disciplinary approach has been employed in this article to re-examine and to reconceptualize the existing landscape of Pakistan-India conflict. An interpersonal conflict model has been used to theorize the emotions found in their bilateral relations which have often been neglected or marginalized while studying their obsessive rivalry vis-à-vis each other. Despite testing the troublesome dyad of these nation-states on diametrically opposite ethnic or religious grounds, this article categorizes Pakistan and India as they are former family members who parted their ways in 1947. This article explains different phases of an interpersonal conflict model and clarifies how the emotional climate associated with these phases could be transposed to an intergroup and interstate level of conflicts between communities who used to live together for centuries, and engage them in a perpetual rivalry.
\end{abstract}

Key Words: India-Pakistan, Emotions, Conflict Model, Obsessive Rivalry, Partition 


\section{Introduction}

India and Pakistan have been locked into an open hostility since their inception. They have fought four conventional wars, and regularly display their nuclear capability to outpace and undermine each other. ${ }^{1}$ Ever since their birth as two separate countries in 1947, India and Pakistan have been psychologically obsessed with their assorted mutual conflicts. From the outside, it resembles nothing so much as a family feud - and psychologically speaking, it's a very apt analogy.

By the time of partition, the two sides had lived together in one society for more than a millennium. South Asian Hindus and Muslims shared not just a cultural gene pool and biological ties, but common kinship institutions: the extended family group joined by marriage, which is called Khandan in Pakistan and Pariwar in India, or the lineage group with common descendants, known as Biradari in Pakistan and Jati in India. Across the Indian Subcontinent, family and lineage are the most influential institutions in people's lives, and people tend to transpose the psychological moral structure of their kinship relations into every other institution in the outside world. Neighbours are also treated as family members; as one famous South Indian proverb puts it, after living together for six months, "they" become "we" and "we" become "they". Also, respecting your seniors and expecting care and nurture is the norm, and it holds sway in various forms across every sphere of life. ${ }^{2}$ This article proposes that it is the violation of these cultural norms that underpins the modern India-Pakistan (or Hindu-Muslim) rivalry making it so emotional in nature.

Viewed this way, the rupture between the two nations can also be traced to what happened within India's predominantly Hindu Congress party in the per-partition period - the party

\footnotetext{
${ }^{1}$ Stephen P. Cohen, Shooting for a century: The India-Pakistan conundrum (Brookings Institution Press, 2013).

2 Sudhir Kakar and and Katharina Kakar, The Indians: Portrait of a people (Penguin Books India, 2009).
} 
which represented both communities against the British Raj in the years before the Partition in 1947. As partition neared, the reservations of Muslims were not properly considered, and their demands were thus not met. The Muslim minority was excluded from most decisions, which created in them a fear of "not mattering at all". The Muslims, suddenly the "junior" family members, felt neglected - and as younger siblings oftentimes do, they became extracompetitive and began to support the two-nations doctrine presented by All India Muslim League; another political party trying to attract the Muslim voters by claiming to be the champion of Muslims' rights. However, India-Pakistan conflict owes more to historical and psychological "nearness" than to mere competition for resources or territory. And that much is clear in the language they use to talk about each other. ${ }^{3}$

In many parts of India and Pakistan, especially in both Punjabs, the word used for the 1947 Partition of British India is "Batwara", which literally means "the distribution of ancestral land" between brothers or patrilineal cousins. The word comes with resonances that the English word "partition” simply doesn't carry: harmonious family, painful division, cousin rivalry, and love-hate competition for generations to come. These are the psychological dynamics that also play out in the dispute over Kashmir. Both India and Pakistan claim Kashmir as if it were their ancestral property, and people on both sides feel a deep emotional attachment to it. In the subcontinent, to give up a claim to one's ancestral property brings "dishonour" to one's family and group, and is considered a weakness. ${ }^{4}$

For Pakistanis, the rivalry against Indians is driven by a deep sense of being humiliated and wronged at the time of partition, the corollary being a "desire" to compete with and trump Indians at any cost. It's this bitterly competitive urge that drives Pakistan's leaders, army

\footnotetext{
3 Jawad Kadir, "Perceiving the Enemy Differently: A Psycho-cultural Analysis of Pakistan-India Conflict." Journal of Asian Security and International Affairs 6, no. 2 (2019): 189-216.

${ }^{4}$ Jawad Kadir, Retrieved at http://theconversation.com/india-and-pakistans-rivalry-isnt-territorial-orideological-its-psychological-91292
} 
officers and populace to defy India's obvious demographic, economic and military supremacy, and to do so with such intensity. As William Blake said "it is easier to forgive an enemy than to forgive a friend". Whoever we are, it seems we can all feel a special kind of enmity for the enemies we most resemble - whether a sibling or a neighbour, we simply cannot accept "them" as "us" despite our obvious similarities, nor we can remain isolated from them. ${ }^{5}$

This article uses a cross-disciplinary approach and seeks to clarify the theoretical mechanism through which family-level emotions are mapped onto the wider societal/national level sentiments and obsessiveness for some other nation. India-Pakistan relations are flooded with emotions and both countries adopt policy standpoints clearly showing an acute anxiety towards each other. While the study of emotions in world politics to analyse diplomacy, statecraft and alliances, sovereignty and peacebuilding is now a widely recognized phenomena, ${ }^{6}$ less efforts are found to explain India-Pakistan rivalry by probing into the construction mechanism of emotions between them. Emotions cannot be removed from their mutual relations; as they lie at the very core of human existence. ${ }^{7}$ This article explains this causal link by drawing upon two interpersonal conflict models presented by Helen Weingarten and Jawad Kadir. ${ }^{8}$ The cognitive neuroscience explanations have also been borrowed to explain how the dynamics of an idealized family model become the source domain for people to conceptualize the functioning of their nation and state. People tend to analogise and conceptualize the difficult or more

\footnotetext{
${ }^{5}$ Anton Blok, "The narcissism of minor differences." European Journal of Social Theory 1, no. 1 (1998): 33-56. ${ }^{6}$ Neta C. Crawford, "The Passion of World Politics: Propositions on Emotion and Emotional Relationships". International Security 24, no. 1 (2000): 116-156, Marcus Holmes, Face-to-Face Diplomacy: Social Neuroscience and International Relations (Cambridge: Cambridge University Press, 2018) and Christian Reus-Smit, "Emotions and the Social". International Theory 6, no. 4 (2014): 568-574.

${ }^{7}$ Jon Elster, Alchemies of the Mind: Rationality and the Emotions (Cambridge: Cambridge University Press, 1999).

${ }^{8}$ Helen R. Weingarten, International Conflict and the Individual: Or, " what Drives that Person with Whom I Have to Negotiate and Can Understanding His Motivation Really Help?". In Zimmerman, William and Harold Karan Jacobson, Behavior, culture, and conflict in world politics. (University of Michigan Press, 1993) and Jawad Kadir, Perceiving the Enemy Differently
} 
abstract concepts e.g. nation, nationalism, state, and intergroup conflict in terms of relatively easier and concrete concepts e.g. family and family conflict. People also use the metaphors reserved within the domain of local, easier and concrete concepts of family conflicts to reason about relatively more difficult and abstract concepts such as intergroup or interstate conflict.

\section{The Conceptualization of Nation in terms of "Family" Model}

Logically enough, an analysis of a nation's behaviour towards other nations requires to explore first into how people conceptualize and perceive each other. Therefore, this article presents an interpersonal conflict model to interpret interstate relations between India and Pakistan due to an acute emotional nature of their rivalry. While trying to test the different levels of conflict identified in family settings to that of the levels of conflict in world politics, several inferences emerge from a causal effort to analogize the typology of family conflicts to world politics: first, while conflict between families and states is inevitable, it is important to differentiate between different levels of conflict in both settings. Secondly, as families are systems, so are states. ${ }^{9}$ Third, it is disputant parties' intentions that matter while perceiving the "other" and interpreting the reality. ${ }^{10}$

Helen Weingarten presented an interpersonal conflict model elaborating a five level scheme that nicely emphasises the sentiments, intensity of conflict, the intentions of the participants and the likelihood of cooperation. ${ }^{11}$ The model examines the major objectives of the participants, the motive or aim of the participants, the emotional climate in the dispute, and the negotiation styles.

\footnotetext{
${ }^{9}$ William Zimmerman and Karan Harold Jacobson, Behavior, culture, and conflict in world politics (University of Michigan Press, 1993).

${ }^{10}$ Jawad Kadir, Perceiving the Enemy Differently.

${ }^{11}$ Weingarten, International Conflict and the Individual, 177.
} 
The interpersonal conflict model was first developed and applied upon an organizational context, ${ }^{12}$ then extended and refined to resolve family disputes. ${ }^{13}$ It has now contributed to understanding and adopting effective strategy for conflict management in international disputes. The key to employ this model is in using its attributes to analyse/resolve international disputes and to provide disputants with a framework to re-assess their conflicts. While the intervention strategies that work with marital partners in conflict have been found equally effective with business associates or neighbours, it is equally anticipated that additional strategies will be needed in international conflict situations in which language, culture, and political ideology and structures radically differ. ${ }^{14}$

In the context of family conflicts, practitioners long ago abandoned the assumption that people render decisions rationally. They favour the proposition that people select means and goals primarily on the basis of their values, emotions, and social bonds. So, the assumption that people choose to maximize their utility in their intergroup conflict (usually identified as group or national interest) has been replaced by the proposition that people have multiple objectives that include, but are not limited to, needs to solve problems, to maintain self-esteem, to win, to control others, to stabilize power, and, to enact revenge. ${ }^{15}$

Rationality is also a by-product of emotions which always shape the way we feel and develop our perceptions. Rationality necessarily contains emotions, just as thinking does feeling. Emotions, in turn, are deeply embedded within the social structures that underpin societies and their politics. ${ }^{16}$ Political science and anthropology provide ample evidence that the degree to

\footnotetext{
${ }^{12}$ Speed B. Leas, Moving your church through conflict (Washington, DC: Alban Institute, 1985).

${ }^{13}$ Helen Weingarten and Speed Leas, "Levels of marital conflict model: A guide to assessment and intervention in troubled marriages." American Journal of Orthopsychiatry 57, no. 3 (1987): 407-417.

${ }^{14}$ Weingarten, International Conflict and the Individual, 180.

${ }^{15}$ Helen Weingarten and Speed Leas, "Levels of marital conflict model: A guide to assessment and intervention in troubled marriages." American Journal of Orthopsychiatry 57, no. 3 (1987): 407-417.

${ }^{16}$ Jack M. Barbalet, Emotion, Social Theory, and Social Structure (Cambridge: Cambridge University Press, 2001).
} 
which different cultures depend on competition to organize and structure their political, economic, educational, or recreational systems varies broadly. ${ }^{17}$ Therefore, rather being innate or biological, emotions can also be socially and culturally constructed. ${ }^{18}$ Emotions are deeply interwoven with the cultural environments. It implies that the processes of decision-making, policy development and practices of cooperation or resistance are developed through how individuals and communities have been socialized to feel. By accepting this social nature of emotions and rationality, we can change the way we theorize interstate relations. ${ }^{19}$ This involves the concepts from psychology, social psychology, neuroscience, sociology and cultural theory. Consequently, this article typologizes national emotions by using two interpersonal conflict models as analogy.

This article does not reject that the factor of 'rationality' in conflict is always denied. However, a working definition of rationality based upon emotions-as-end, as an efficient choice of means to advance one's goal is presupposed. The conflict models clarify the factors that influence the exercise of rationality in conflict interaction and to identify the motives, goals, emotions and cognitions that thereby play a critical role in shaping conflict behaviour. It is individual differences in motivation and their worldviews that systematically influence approaches to deal in with contested issues.

According to Weingarten, the five phases or levels in family conflict are: problems to solve, disagreements, contests, fights, and war. Each level has different emotions and characteristic attributes. For example, in a level-I conflict, the disputants remain emotionally hopeful to

\footnotetext{
${ }^{17}$ Alfie Kohn, "No contest: The case against competition." (Boston: Houghton Mifflin, 1986).

${ }^{18}$ Catherine A. Lutz, Unnatural Emotions: Everyday Sentiments on a Micronesian Atoll and Their Challenge to Western Theory (Chicago: University of Chicago Press, 1988).

${ }^{19}$ Emma Hutchison, Affective Communities in World Politics: Collective Emotions After Trauma (Cambridge: Cambridge University Press, 2016).
} 
resolve their mutual issues and an "open, direct, clear" communication between the parties takes place. In a level-II conflict, the key focus is of "self-protection, but the compromise is also considered necessary while the emotional climate is of uncertainty. In the next stage (levelIII conflict), the desire of winning comes over surface due to climate of frustration. In level-IV conflict, the players aim at hurting each other as they feel that winning over the other is impossible. In a family war stage (level-V conflict), the destruction of enemy - usually former blood relation (wife or brother) - becomes the main goal, force may be used, and the relevance of specific issues disappears. The dispute becomes one about the opponent's personality, and indeed the opponent is seen as "less inhuman than oneself". ${ }^{20}$

Notably, the interpersonal conflict model only provides general guidelines for how to develop macro-level conflict models in different societies to resolve conflict at different levels. It is appropriate to mention here that our values and behaviour are shaped through early cultural experiences (Triandis, 1989), the conflict dynamics learned within the native institution of the family remain at the core of peoples' cognitive interpretations of wider events and subsequent emotional responses (Ross, 1995). In understanding the emotional side of intergroup conflicts, we must consider the dynamics of the family amongst the people of a particular area. For this reason, an indigenous family conflict model known as Sharike-Bazi in the Indian subcontinent (Kadir, 2019) ${ }^{21}$, has also been borrowed to compare with the Weingarten's model in order to examine the emotional climate and interpersonal conflict dynamics among the ordinary people and leading political figures in the Indian pre-partition and post-partition periods.

This indigenous model presented by Kadir (2019) highlights the segmentation process of a harmonious joint family in the Indian Subcontinent and thus the demands of separation by one branch of the family from the 'other' - the demands arising out of being neglected and not

\footnotetext{
${ }^{20}$ Zimmerman and Jacobson, Behavior, culture, and conflict in world politics, 7.

${ }^{21}$ Jawad Kadir, Perceiving the Enemy Differently
} 
being accommodated and respected in the joint family setup. It disrupts the harmony of relations between branch members of the same family. This usually happens after the demise of the father (s) or other elder figures in the joint-family who would have been responsible for maintaining the integrity of the family. Usually, a departing brother (or brothers) perceives that he has been denied a fair share and has been wronged and cheated over resource distribution, including wealth as well as status. The 'wronged' brother (s) then becomes extra competitive to right the wrong done to him and to get back his lost prestige. He might seek help from outside of his family or lineage to settle scores with his family members. The remaining family block, on the other hand, always try to undermine the new identity of their departing brother (s). They always blame the departing brother (s) for sowing the seeds of disunity in the family. Furthermore, this bitterness passes on to future generations, engaging them in turn in a sort of intimate rivalry. The key point to consider in this model is that: even after parting their ways, the different branches of the family remain obsessed with one another.

Arguably, within both these models, the presence of conflict per se is not viewed as a sign that relationship or organization or nation is in trouble, rather they present the conflictual/cooperative nature of a social system. It is the view that how people handle the conflicts that inevitably arise that strengthens or weakens their relationships, and social systems of which they are a part. ${ }^{22}$ Simply put, people's selection of approaches to deal with the conflict (conflict behaviour) is determined by socio-cultural norms to which they are a part. It is not always the substantive part of the conflict that matters but other non-substantive or the passions associated with the conflict can also be crucial in selecting the future path by the principal disputants.

\footnotetext{
${ }^{22}$ Weingarten, International Conflict and the Individual, 178.
} 


\section{The Mechanism of Conceptual Mapping: A Theoretical Understanding}

Cognitive science research has long established that the mechanism which allows people to reason about abstract ideas in forms of more concrete, experience-based knowledge is "conceptual metaphor" - many of such metaphors are automatically acquired based on everyday experiences, primarily at the early stages of life when basic neural patterns are being formed and strengthened in the mind..$^{23}$ The transposition of such interpersonal conflict models onto intergroup as well as interstate relations can be explained through the cognitive neuroscience research. Cognitive neuroscience research has it that we conceptualize nation on the same cognitive patterns as we conceptualize other abstract entities through cognitive modelling or metaphor, which is called "conceptual metaphor". ${ }^{24}$ As discussed by Lakoff and Johnson, Metaphors are (unconsciously) used to set up parallels between difficult and easy concepts. ${ }^{25}$ They have problem-solving functionality to solve an ill-understood phenomenon by recalling a better-understood phenomenon. For example, when people say that “don't waste your time", they (unconsciously) use the metaphor of money for time, which should not be wasted.

Theoretically, in the context of intergroup or interstate conflict, the principal parties are to be conceptualized as former family members. Here, the conceptual metaphors of nation-as-family or nation-as-person come into play. Both are quite famous in international relations. Anderson had pointed out that we cannot experience the nation directly, therefore, we imagine it in terms of some community which is necessarily imaginary. ${ }^{26}$ As nation is definitely an abstract concept, therefore it is thought upon by people in relation to more understandable or concrete

\footnotetext{
${ }^{23}$ George Lakoff and Mark Johnson, Metaphors we live by (Chicago, IL: University of Chicago Press, 1980).

${ }^{24}$ Patrick Colm Hogan, Understanding nationalism: On narrative, cognitive science, and identity. (The Ohio State University Press, 2009), 124.

${ }^{25}$ Lakoff and Johnson, Metaphors we live by.

${ }^{26}$ Benedict Anderson, Imagined Communities: Reflections on the Origin and Spread of Nationalism (London: Verso, 1983).
} 
concepts. The behaviour of a nation can be examined by exploring into the concrete concepts/models people usually rely upon for conceptualizing their nation. Connor associates national community with the family and goes so far as to define the nation as "the fully extended family". ${ }^{27} \mathrm{He}$ suggests that the nation works its magic through "familial metaphors". ${ }^{28}$

The type of family model idealized by people has deep impact on running a nation's affairs. Lakoff has discussed that such metaphorical understanding of the nation-as-family directly informs our political worldview; 'Directly, but not consciously'.29 The idealized family models produce certain moral systems for running a nation and functionality of the state. The individual actors map these moralities of their ideal family models onto the societal/national domain by engaging the nation-as-family metaphor, which facilitates reasoning about the abstract world (the state) in term of more concrete and daily based world experiences, i.e. family life.

This article argues that national conflict is also a highly abstract idea which is automatically (but unconsciously) conceptualized in terms of more easier but similar concrete concepts, i.e. family level conflict behaviour. Lakoff's study is aimed at exploring where do national level political attitudes come from while this article examines that from where do national level sentiments emerge in Pakistan-India conflict. This article argues that the emotional climate associated with joint/extended family in both countries act as source domain for people to behave against each other at national level. People and political actors at the helm of decisionmaking, might use these emotions and conflict dynamics practiced within their family feuds, and map these patterns onto their national-level conflicts making them intractable in nature.

\footnotetext{
${ }^{27}$ Walker Connor, Ethnonationalism : The Quest for Understanding. (Princeton, N.J.: Princeton University Press, 1994), 202.

${ }^{28}$ Ibid., 94.

29 George Lakoff, Moral politics: How conservatives and liberals think ( Chicago, IL: University of Chicago Press, 1996).
} 
These dynamics become even more visible especially against outgroups with whom people share a number of commonalities ranging from geographic proximity to identical kinship structures. In sum, India-Pakistan interstate conflict, being an abstract concept, is being conceptualized by people in terms of their personally experienced inter-family conflicts (concrete ones).

\section{Pakistan-India conflict: An Ethno-Religious Conflict or A Family Split}

It is appropriate to mention here that the metaphor of family cannot be excluded from the inquiry if we wish to study the affective side of India-Pakistan rivalry as the family (joint family to be specific) is the most salient, initial, most emotionally powerful, most functional, and the most enduring institution in this region. ${ }^{30}$ Traditionally, India-Pakistan conflict has been explained by assigning both nations fixed rather diametrically opposite ethno-religious categories i.e. Hindus and Muslims, which is theoretically problematic, and, does not explain the emotional side of this conflict. The term 'ethno-religious', itself is an amalgam of two different cultural identities; religion and ethnicity. There has always been a paradox of identity for both Hindus and Muslims in the subcontinent due to a complex criss-crossing of their common caste identities as well as the massive assimilation process due to mass-conversion from one religion to another. They were caught in the web of deciding between different cultural identities; religious and kinship identities being top of the list. This fact must not be ignored that despite having different religions, large number of people belonged to same ethnic groups and castes. For example, Punjabi or Bengali population was divided on religion factor during partition despite belonging to same ethnic group. In spite of different religions, people

\footnotetext{
${ }^{30}$ Anatol Lieven, Pakistan: A hard country (London: Public Affairs, 2012).
} 
having similar ethnic, religious, linguistic and even kinship ties co-existed for centuries. Still, same is the case mostly in India, and to some extent in Pakistan.

Primarily, there are two distinct ways in which the term "ethnic" has been used by the political scientists. In its narrower sense, "ethnic" means "racial" or "linguistic". ${ }^{31}$ This is the sense in which the term is widely understood in popular discourse. However, in British India, the term "communalism" has been used more often to mention conflicts between Hindus and Muslims based upon religious differences because of both groups' overlapping racial, ethnic and linguistic roots.. ${ }^{32}$ Defining the term 'ethnic' so could not differentiate between Punjabi Hindus/Muslims or Bengali Hindus/Muslims. Therefore, we will have to subscribe to another broader sense of defining ethnic groups in social sciences. All conflicts, Horowitz argues, based upon ascriptive identities - race, language religion, tribe, or caste can be called ethnic. Even the groups differentiated by 'nationalities' come under this wider umbrella of ethnicity. ${ }^{33}$ In this wider concept, ethnic conflicts range from Protestant-Catholic conflict in Northern Ireland, and Hindu-Muslim conflict in post-partition and pre-partition period. The black-white conflict in United States and South Africa also comes under its rubric. ${ }^{34}$ Using this wider criteria of defining ethnicity is also problematic, because not only the interstate Pakistan-India conflict or intra-state Tamil-Sinhala conflict in Sri Lanka, but Shia-Sunni sectarian conflict in Pakistan can also be regarded as ethnic conflicts.

According to Weingarten's Conflict model, the disputants at level-I tend to express a sense of individual responsibility and tend to resolve the problems themselves. They are able to focus on substantive issues and differentiate between the problem and the people involved in it. An optimistic climate makes direct communication possible between the parties. Level-I of

\footnotetext{
${ }^{31}$ Ashutosh Varshney, Ethnic conflict and civic life: Hindus and Muslims in India (Yale University Press, 2003), 4.

32 Ibid

${ }^{33}$ Donald L. Horowitz, Ethnic groups in conflict (Berkley: University of California Press, 2001), 53.

${ }^{34}$ Ibid
} 
Weingarten's model resembles to the Harmonious-Family phase presented by Kadir (2019) in which family members are able to reconcile their differences by talking out their heart.

In the Indian context at this stage, the wonderful efforts on the part of two individuals cannot be overemphasized while reconciling the differences between Hindu and Muslim communities in the early twentieth century. Mr. Bal Gangadhar Tilak (a Hindu) and Mr. Jinnah (a Muslim) were the leading members of Indian National Congress. They were succeeded in resolving the Hindu-Muslim problem in Lucknow Pact, 1916. Mr. Jinnah was also representing the All India Muslim League during the proceedings of this agreement - the agreement that had provided Muslim minority with the safeguards of separate electorate and meaningful representation in the central legislature. Both the leading parties held their meetings together to discuss their common interests, and substantive parts of Hindu-Muslim dispute to resolve them accordingly. ${ }^{35}$

At level-II, the focus on substantive solving changes to the concern with establishing a safe and trustworthy relationship. The emotional climate of uncertainty develops making 'trust' a critical dynamic at this level. Therefore, the principal actors at this level avoid confronting one another directly about their concerns and disagreements. Direct communication diminishes and people start looking for help and enlist friends to discuss problems and seek advice. Now, they seek third party intervention but third party intervention can easily escalate interpersonal mistrust. ${ }^{36}$ Although parties are ambivalent about the compromises, still they are willing to resolve their differences from a defensive stand-point.

The level-II conflict is the period when trust deficit between Hindu-Muslim or CongressMuslim League grew during late 1920s and early 1930s - after the honeymoon period of

\footnotetext{
${ }^{35}$ Ian Bryant Wells, Ambassador of Hindu-Muslim Unity: Jinnah's Early Politics (New Delhi: Permanent Black, 2005).

${ }^{36}$ Weingarten, International Conflict and the Individual, 183.
} 
Khilafat movement (1915-23) between both communities. ${ }^{37}$ Several attempts were taken by both parties to resolve their issues. Delhi Proposals presented by Jinnah in 1927 and Motilal Nehru Report in 1928 can be regarded as a few of such attempts aiming at brokering some agreement between both communities. The mediation from colonial masters was also sought for during this period (Round table conferences, 1930-32), which actually escalated the intensity of their conflict. This time-period can be attributed as a war of succession in Congress family when the prominent leaders struggled to attain the Congress headship after the demise of its father-figures such as Gokhale, Tilak, Naoroji and Pherozesha Mehta. Their interpersonal conflicts did not allow them to think about the combined threat to both communities they were leading.

At level-III contest, the emotional climate is one of frustration and resentment and the hope diminishes that mutual problems can be solved. Anger erupts easily - often over issues the disputants themselves view as trivial - and dissipates slowly. Disputants lose sight of their potential common interests and interdependence. This level stresses the right of persons to act independently. The issues are piled up and are hard to disentangle. People no longer find it easy to talk to one another informally. While the contestants are profoundly concerned with control and power, they recognize that it will be impossible to achieve these ends if their relationship to one another is entirely severed. This is the phase when one branch of family in the indigenous family settings of the Indian Subcontinent starts thinking of separation from the other branch. This is the level of conflict in which disputants identify 'freedom' and

\footnotetext{
37 The Khilafat movement (1919-1924) was an agitation by Indian Muslims allied with Indian nationalism led by Gandhi in the years following World War I. Its purpose was to pressure the British government to preserve the authority of the Ottoman Sultan as Caliph of Islam following the breakup of the Ottoman Empire at the end of the war. Many prominent Muslim and Hindu leaders joined their hands against the British rulers during this movement.
} 
'independence' as their most cherished values and then wonder why the victories they achieve at other's expense seem hollow. ${ }^{38}$

In India-Pakistan context, Level-III indicates at the time period after 1937 when Congress assumed power and outclassed Muslim League in their claim for representing Muslim population. Muslim Leaguers felt cornered, and mobilized their supporters in pursuit of Azadi (independence). During this stage, trivial religious issues could engage both communities into fatal clashes. Popular leaders such as Jinnah, Gandhi, Nehru, and Azad from the both parties were not on good speaking terms during this period. They preferred to address and bash one another through the medium of newspapers. They had lost sight of their common future. However, they collaborated with each other in the interim government, 1946, in order to achieve their individualistic goals. After achieving their diametrical opposite goals, both parties had felt that victory was far from what they had thought. There are many statements on the part of leaders from both groups which reveals no one was ready for such devastation at the time of partition. A very famous Urdu poet Faiz Ahmed Faiz depicts a gloomy picture of the emotional climate generated after parting ways from each other. Faiz is equally cherished in both the countries. He says: in the name of independence, people had lost everything:

This leprous daybreak, dawn night's fangs have mangled -

This is not that long-looked-for break of day, Not that clear dawn in quest of which those comrades

Set out, believing that in heaven's wide void Somewhere must be the stars' last halting-place, Somewhere the verge of night's slow-washing tide, Somewhere an anchorage for the ship of heartache. When we set out, we friends, taking youth's secret Pathways, how many hands plucked at our sleeves! From beauty's dwellings and their panting casements Soft arms invoked us, flesh cried out to us; But dearer was the lure of dawn's bright cheek, Closer her shimmering robe of fairy rays; Light-winged that longing, feather-light that toil. But now, word goes, the birth of day from darkness

\footnotetext{
${ }^{38}$ Ibid., 185
} 
Is finished, wandering feet stand at their goal;

Our leaders' ways are altering, festive looks

Are all the fashion, discontent reproved; -

And yet this physic still on unslaked eye

Or heart fevered by severance works no cure.

Where did that fine breeze, that the wayside lamp

Has not once felt, blow from - where has it fled?

Night's heaviness is unlessened still, the hour

Of mind and spirit's ransom has not struck;

Let us go on, our goal is not reached yet. ${ }^{39}$

At level-IV and afterwards, contestants often feel satisfied by getting rid of the other. The emotional climate of antagonism as well as alienation from the other group surpasses all the other realities. The outsiders are enlisted not to 'save' the relationship between parties at this level but to as allies to change the status quo. Each side believes that other side cannot or will not change. Indeed, when the other side attempts to modify its position, its motives are questioned and charges of hypocrisy or manipulation are levelled. Groups or individuals have to prove their loyalty who wish to become part of ingroup. Individuals become fixed on ideology and their own personal (or subgroup) agenda. Commonly they lose sight of the importance of community, diversity and relationship. Charismatic group leaders often emerge at this stage who are comfortable with leadership role and the exercise of power. The contestants at this level envision themselves as guardians of fundamentally exclusive principles. $^{40}$

Level-IV phase can be traced when Pakistan movement was at its peak in the mid-1940s. Muslim League was claiming to be the sole representative of the Muslims. A separate homeland was set as a final goal. All the Muslims were asked to join Muslim League otherwise their loyalty could become suspicious. The Muslim leaders not in line with the demand of

\footnotetext{
${ }^{39}$ Translated by V.G. Kiernan Retrieved at https://rashidali.wordpress.com/2012/05/13/yeh-dagh-dagh-ujalafaiz-ahmad-faiz/

${ }^{40}$ Weingarten, International Conflict and the Individual, 190.
} 
separate homeland were considered dishonest to the Muslim cause. Subsequently, the slogan "Muslim ha to League me aa" (join Muslim League, if you are a Muslim) became much popular during this period. An emotional climate was there among the Muslim league workers to get rid of Hindu leadership at any cost. It was an era of charismatic leaders such as Gandhi, Jinnah, Bose and Jawaharlal Nehru among both parties. The famous Gandhi-Jinnah talks, 1944, flopped owing to suspicion for each other. Gandhi had literally used the analogy of family feud among brothers for Hindu-Muslim conflict and tried to resolve it. Jinnah was not ready to modify his position at any cost because it was too late and the magnitude of mistrust had touched irreversible heights. At this level, the sincere reconciliatory efforts of Gandhi were suspected by certain quarters of Muslims and charges of hypocrisy were framed against him.

It is not to say that the entire Muslim leadership was in favour of Partition. Many Muslim leaders including top Muslim clergy such as Maulana Abul Kalam Azad (Congress), Maulana Muhammad Hassan Madni (Jamiat Ulma-e-Hind), Maulana Maududi (Jamaat-e-Islami) and Ata Ullah Shah Bukhari (Majlis-e-Ahrar) had rejected the idea of Muslim nationalism presented by Muslim League and equated it to a "curse". ${ }^{41}$ All the first rank Muslim clerics blamed Muslim League leaders to protect the British raj and called the Hindu-Muslim conflict "nothing more than friction between two brothers over the distribution of their father's property". ${ }^{42}$ A rejoinder to Muslim Leagues' Lahore's Resolution demanding a separate state, was given by the then Congress President Maulana Abul Kalam Azad in the following words:

"Eleven hundred years of common history [of Islam and Hinduism] have enriched India with our common achievements. Our language, our poetry, our literature, our culture, our art, our dress, our manners and customs, the innumerable happenings of our daily life, everything bears the stamp of our joint endeavour ... These thousand years of our joint life [have] molded us into a common nationality ... Whether we like it or not, we have become

\footnotetext{
${ }^{41}$ Ian Talbot, "Back to the future? Pakistan, history and nation building," in Pakistan at the Millennium, ed., C.H. Kennedy (Karachi: Oxford University Press, 2003), 65:95 and Syed Anwar Hussain, Pakistan: Islam, politics, and national solidarity (Praeger Publishers, 1982).

42 Salil Misra, A Narrative of Communal Politics, Uttar Pardesh, 1937-39 (California: Sage publications Inc., Thousand Oaks), 235.
} 
one Indian nation, united and indivisible. No fantasy or artificial scheming to separate and divide can break this unity". ${ }^{3}$

Hindu-Muslim conflict also owed to socio-economic and political factors. ${ }^{44}$ The proponents of this approach say that during the early period of British rule, the Muslims were lagged far behind to Hindus in educational, economic, political, administrative and professional fields. ${ }^{45}$ As Muslim elite's domination over society was threatened, they tried to mobilise their own community behind them through manipulating identity symbols; religious and linguistic. ${ }^{46}$ In so doing, this approach points its fingers at the Muslim elite/aristocrats in minority Muslim provinces (Aligarh's Muslim Elite) as an exploiting class, who made use of religion for securing their own political and economic interests - Jinnah's westernised personality is presented to substantiate this argument. Jalal argues that Jinnah was a political strategist who played the majority Muslim province card originally to secure the best position in a united India; actually he never wished to leave the federation but ended up having to do so. ${ }^{47}$ However, in the end, Jinnah "the ambassador of Hindu-Muslim unity" when reconciled himself to the idea of two nations as religiously, culturally, and historically different, he brought it to its logical ending of carving out a separate statehood by the force of his indomitable will. ${ }^{48}$

In the final phase, the conflict becomes intractable as is the case of India and Pakistan now. The claims of one party are perceived by the other party as a threat to its ontological security. ${ }^{49}$

\footnotetext{
${ }^{43}$ Ramchandra Guha, India After Gandhi: The History of the World's Largest Democracy (New York: HarperCollins, 2007), 41.

${ }^{44}$ Paul R. Brass, Language, Religion and Politics in India (London: Cambridge University Press, 1974) and "Elite group, symbol manipulation and David T. Taylor and Malcolm Yapp (ed.), Ethnic identity among the Muslims of South Asia" in Political Identity in South Asia, (London, Curzon Press, 1979).

${ }^{45}$ Louis Dumont, "Nationalism and Communalism", in Religion,/Politics and History in India (Paris: Mouton De Gruyter, 1970), 98:99.

${ }^{46}$ Maulana Abul Kalam Azad, India wins Freedom (The Complete Version, New Delhi [India]: Orient Blackswan Private Limited, 2014).

${ }^{47}$ Ayesha Jalal, The Sole Spokesman: Jinnah, the Muslim League, and the Demand for Pakistan (Cambridge University Press, 1985).

${ }^{48}$ Stanley Wolpert, Jinnah of Pakistan (New York: Oxford University Press, 1984), vii.

${ }^{49}$ States do not merely seek physical security but also ontological security, i.e. the security of the state selfidentity. States are thus not only interested in survival (as realists assert) but also in the continuation of the self, i.e. the confidence that the self will prevail in the international order. Sometimes, this interest in ontological
} 
Enemies during this phase experience high anxiety, which they believe can only be assuaged by defeating or eliminating the other. The disputants are neither able to understand their issues clearly nor they can disengage themselves from each other. Final phase depicts the picture of post-partition Pakistan-India conflict where both nations are obsessed with each other and each nation has acquired the status of eternal enemy for the other. Pakistan's ontological security comes under threat if someone strives to seek better relations with India and vice versa. To compete the other has become the foremost policy-objective for both nations; an emotional cricket rivalry is only one of many examples. In this connection, a note to US Secretary Dulles by the President Eisenhower in 1953 is very interesting in which he stated his fears when he remarked that in South Asia "emotions rather than reason seems to dictate policy." The US often had to choose between either India or Pakistan. Dulles' reply showed the extent to which the American administration understood the problem: "It is difficult to help one without making an enemy of the other". ${ }^{50}$ It became really a daunting task for the US administration to keep both India and Pakistan simultaneously happy as any support the US gave one country was seen in a negative light by the other.

The final phase of the interpersonal conflict model also owes to the disputants' contradictory views regarding the distribution of assets between them. The parties develop the perception that she was wronged by the other. Similarly, the major argument was of "parity" advanced by Muslim League for an independent Pakistan that irrespective of population, Hindus and Muslims should be treated as two separate and equal nations. The Muslim League referred to this demand as doctrine of parity. On the other hand, some congress' leaders such as Sardar Patel were unwilling to concede parity to the Muslim League even at the the cost of sacrificing

\footnotetext{
security might conflict with the interest in physical security, and states might risk physical insecurity for ontological security. Jennifer Mitzen, 2006. "Ontological Security in World Politics: State Identity and the Security Dilemma." European Journal of International Relations (12(3)): 341-70.

${ }^{50}$ Eisenhower's note to Dulles and Dulles reply, November 16, 1953. Dennis Kux, Disenchanted Allies: The United States and Pakistan, 1947-2000 (Baltimore: Johns Hopkins University Press, 2001), 58-59.
} 
the dream of a united Indian family. He had categorically informed the last Viceroy of India, the Lord Mountbatten that: "If you raise the question of parity you will incur the everlasting enmity of Congress; that is the one thing we have been fighting against and will never agree to". 51

After the creation of Pakistan, obviously Pakistan wished an economic and military parity with India in terms of united India's assets. However, being wronged at the time of partition has always been Pakistani narrative. One Pakistani prime minister, Zulfikar Bhutto, complained about unfair distribution of assets as:

"The British Government could not have done more to tilt the balance of advantage in India's favour.... No attempt was made to provide Pakistan with the minimum requirements for administration, defence, and finance. The country was left to fend for herself. In the maintenance of law and order, the division of assets, military stores, and sterling balances, and even in the transfer of funds, India was given a stranglehold over Pakistan". ${ }^{52}$

\section{The Family Metaphors used in Pakistan-India Partition}

This section is aimed at delving into language used by both parties, which is always directly connected to the unconscious conceptual systems and metaphors. ${ }^{53}$ How we talk matters; one can learn a lot about how people frame situations from how they talk. The language that common people and political leaders in both India and Pakistan use against each other is particularly related to local family dynamics. The case of utilizing an indigenous family model is also strengthened by finding the heavily familistic language used by both parties. For example, two terms (or metaphors) broadly used by people on both sides to memorise and explain their split are Qaum and Batwara. The term "Batwara", for example, is used to mention

\footnotetext{
${ }^{51}$ Nicholas Mansergh (ed.), Transfer of Power Documents, "Viceroy's report No. 4,"24 April 1947, Vol. 10, p. 407, cited in Aparna Pande, Explaining Pakistan's Foreign Policy (Oxon: Routledge, 2011), p. 13.

${ }^{52}$ Zulfiqar Ali Bhutto, The myth of independence (London: Oxford University Press, 1969), Chapter 18.

${ }^{53}$ George Lakoff, Lakoff, George. "Metaphorical Thought in Foreign Policy: Why Strategic Framing Matters To the Global Interdependence Initiative." 1999.
} 
the Pakistan-India partition in 1947, which is a term reserved for split/asset distribution between blood brothers/cousins. An overwhelming number of people across much of the northern part of the subcontinent recall the event of partition as Vibhajan or Batwara rather than freedom (Azadi). ${ }^{54}$ They do not take the great tragedy of partition just as creation of two nation-states but the meaning they attach to this tragic event is derived from the emptional connotation of 'Batwara'.

The meaning and fantasies people attach to different words in different cultures is always relevant to understand objective realities. Only translating different words to foreign languages might mislead the academic investigation. The meanings attached to the word 'Batwara' for British India's partition open new vistas for understanding that how Indian and Pakistanis are obsessed about this rivalry. The frames, scripts, memories, and meanings attached to the metaphor of Batwara used for Pakistan-India conflict, (unconsciously) guide people to be engaged in a sort of intimate family rivalry. These metaphors create heavily familistic images into peoples' minds and act as a source domain while conceptualizing the 'other'. The phrase "partition of British India" cannot give readers the exact concepts and fantasies attached to the word 'Batwara' used locally for Pakistan-India partition, which brings the conflict dynamics of partition of a joint family into foreplay, not of two ethnic, religious or national groups.

Similarly, the term 'Qaum' that was/is widely used to categorize Hindus and Muslims as different nations, which was/is originally used for Biradari/Jati/lineage group in subcontinent. Both these terms (Qaum and Batwara) serve the purpose of conceptual metaphors for both groups to situate their identity in difference with each other. Here, the word 'Qaum' needs explanation as it serves more than one contexts. An examination of the term "Qaum" lets us to

\footnotetext{
54 Tai Yong Tan and, Gyanesh Kudaisya, Aftermath of Partition in South Asia (Routledge Studies in the Modern History of Asia ; 3. London: Routledge, 2000), 30.
} 
explore that both groups had conceptualized their nations or Qaum in terms of a larger family group.

The basic usage of the word Qaum has been to represent Biradari (Jati) in the Indian subcontinent for centuries. The terms Qaum, Biradari and Jati (Brotherhood) are synonyms which denote a group of people having common descendant; a sort of large paternal family group. ${ }^{55}$ Sadly, there is no other appropriate word in Urdu to translate 'nation' other than Qaum. Therefore, the term Qaum is used both for a Biradari and the nation. The term Vatan is also used to represent one's country. It should not be confused with the term Qaum, as the term Vatan represents the country's territory; a home-land but not the population. Vatan stands for "home-country", a territorial connotation; a place to be shared by the people belonging to one nation or Qaum (in the indigenous sense).

The word 'Qaum' was not used to demand a separate territorial state because the modern western concepts of the nation, nationalism, state, and communalism were quite unfamiliar in the Indian Subcontinent up till the late nineteenth century - and ideally these foreign concepts were to be digested by local people after situating them along with their indigenous and mundane concepts. Hence, they were conceptualized in relatively easier and concrete concepts, for example, family and Biradari. Sadly, both culture oriented and instrumentalist theories to explain Hindu-Muslim split by Robinson and Brass respectively ${ }^{56}$, do not explore the indigenous conceptualization of nation in terms of family.

The Subaltern school of thought hold British rulers responsible for fostering and concretizing the communal identities between both sister-communities for their political gain. ${ }^{57}$ Pandey

\footnotetext{
${ }^{55}$ Hamza A. Alavi, "Kinship in west Punjab villages." Contributions to Indian Sociology 6, no. 1 (1972): 1-27.

${ }^{56}$ Francis Robinson, Separatism among Indian Muslims: The Politics of the United Provinces' Muslims, 18601923 (London: Cambridge University Press, 1974) and Paul R. Brass, Language, Religion and Politics in India (London: Cambridge University Press, 1974).

${ }^{57}$ A school pioneered by Ranajit Guha. See for a detailed discussion: Ranajit Guha, An Indian Historiography of India: A Nineteenth Century Agenda and its Implications (Calcutta, K.P. Bagchi \& Co., 1988).
} 
suggests that the Muslims in south Asia were linguistically and culturally so diverse, that they could not identify a water-tight "Muslim" identity for themselves only by shared beliefs or religion. ${ }^{58}$ Interestingly, the Subaltern notion of "British conspiracy" is shared by both nations but from different emotional standpoints: Indians believe that the British supported Muslim League to counter Indian National Congress during their Raj while the Pakistanis blame the British rulers for their injustice to Pakistan while partitioning British India and distributing the combined resources. A different view is explained by Professor Hutchins from a soft perspective that the "illusion of permanence" was purposefully generated by the British elite in the name of their civilizing and democratization mission in India - the elite whose authority and status was at decline due to increasing democratization of English politics. ${ }^{59}$ Such an illusion worked both ways; for the rulers as well as for their subjects who were made to believe that certain quarters of the Indian society were a hurdle in the way of enlightenment, and that the independence for an unreformed India was unthinkable.

For these obvious reasons, even the leading Muslim ideologues such as Sir Syed Ahmad Khan could not be able to imagine a separate state for the Muslim nation (Qaum). He was not even in the favour of a country-wide Muslim organizations and never mentioned the word "Qaum" to express Muslim solidarity across borders. He disapproved of Muslim Ottoman Caliphate's claim for being commander of the faithful throughout the world. ${ }^{60}$

Syed Ahmad Khan believed that India was home to both Hindus and Muslim communities:

"Just as the high caste Hindus came and settled down in this land once, forgot where their earlier home was and considered India to be their own country, the Muslims also

\footnotetext{
${ }^{58}$ Gyanendra Pandey, The Colonial Construction of Communalism in North India (Delhi: Oxford University Press, 1990).

${ }^{59}$ Francis G. Hutchins, The Illusion of Permanence : British Imperialism in India (Princeton, NJ: Princeton University Press, 1967).

${ }^{60}$ Faisal Devji, Muslim Zion: Pakistan as a Political Idea (London: C. Hurst, 2013), 54.
} 
did exactly the same thing - they also left their climes hundreds of years ago and they also regard this land of India as their very own". ${ }^{61}$

At another place, he presented the idea of a secular Indian nationalism and referred to all religious groups as a single family group (a Qaum):

'We must have heard and read in the history and history books, and, still we see that the word "qaum" applies on the people living in one country. Different people living in Afghanistan are said to be one "qaum". Similarly, different type of people living in Iran are called "Irani". O' Hindu and Muslim! Are you people living in any else country than Hindustan? Are you not buried in the soil of this country or cremated on the cremated grounds of this country. The Mussalman or Christian who live in this country comprise one qaum (nation) in this respect. ${ }^{62}$

On $2^{\text {nd }}$ February 1884 in Lahore, Sir Syed met with a Hindu delegation led by Lala Singh Lal which also included secretary Hindu Sabha Lala Ram Krishan and secretary Arya-Samaj Lala Jeevan Das.

"The word "Hindu" which you use is not correct according to my opinion because it is not the name of any religion. Every person living in Hindustan can claim to be a Hindu. I am extremely sorry that you do not consider me as a "Hindu" despite the fact that I live in Hindustan. You must know that how important it is for the progress of Hindustan that Religiously Hindus and Muslims should work together. Sahibo! (Respected people)! The time is gone when people could be considered separate nations on the basis of religion only'.63

Here, Syed Ahmad Khan had categorically opposed the notion of a territorial nation-state based upon different religions.

It can be argued therefore that although for Muslim elite, the tracing of their racial roots to wider Muslim world could be a source of prestige, however, the source domain for the conceptualization of nation (or Qaum) was related to its indigenous sense which is akin to a lineage group. Syed Ahmad did not see Muslims and Hindus as two separate nations, but as communities destined to work together to build the Indian nation. Therefore, it can be argued

\footnotetext{
${ }^{61}$ Christophe Jaffrelot, The Pakistan Paradox : Instability and Resilience. CERI Series in Comparative Politics (Oxford: Oxford University Press, 2016), 47. A speech made by Sir Syed in 1883.

${ }^{62}$ Syed Iqbal Ali, Sir Syed ka Safarnama Punjab (Lahore: Majlis-e-Taraqa-i-Adab), 132. 27 January, 1884, Syed's address to a reception in his honour in Gurdaspur

63 Ali, Sir Syed ka Safarnama Punjab, 200.
} 
that ethno-religious nationalism associated to him does not bear even the minute traces of separatism other than in the electoral sense. ${ }^{64}$ In his 1883 speech, he also declared:

“... my Hindu brethren and Muslim co-religionists breathe the same air, drink the water of the sacred Ganga and the Jamuna, eat the products of the earth which God has given to this country, live and die together (....) I say with conviction that if we were to disregard for a moment our conception of Godhead, then in all matters of everyday life the Hindus and Muslims really belong to one nation (Qaum) ${ }^{65}$.... I have always said that our land of India is like a newly wedded bride whose two beautiful and luminous eyes are the Hindus and the Musalmans; if the two exist in mutual concord the bride will remain for ever resplendent and becoming, while if they make up their mind to see in different directions the bride is bound to become squinted and even partially blind. ${ }^{66}$

Here, Syed Ahmad Khan used the bride-as-nation metaphor to conceptualize Indian nation to whom both Hindus and Muslims were equally responsible to maintain her beauty and charm.

A year later in 1884 , he added that:

"Do not forget that Hindus and Muslim are words of religious significance otherwise Hindus, Musalmans and Christians who live in this country form one nation (qaum) regardless of their faith. ${ }^{67} \mathrm{He}$ also said that Hindus and Muslim mingled their blood and gave rise to a new culture made of both: "the blood of both have changed, the colour of both have become similar (....) we mixed with each other so much that we produced a new language - Urdu, which was neither our language, nor theirs". ${ }^{68}$

It can be surmised therefore, that the idea put forward by Syed Ahmad Khan was of a distinct Muslim Biradari along with Hindu Biradari; both to live side by side in a grand Hindustani or Indian Biradari. Logically enough, the conflict dynamics between both groups developed similar to that of inter-family or inter-Biradari conflict dynamics replete with deep seated anxieties.

\footnotetext{
${ }^{64}$ Jaffrelot, The Pakistan Paradox, 48.

${ }^{65}$ Shan Muhammad, ed., Writings and Speeches of Syed Ahmad Khan, (Bombay, Nachiketa Publications, 1972), 160 .

${ }^{66}$ Vishwanath Prasad Varma, Modern Indian Political Thought (Agra, Lakshmi Narain Agarwal, 1980), 430 cited in Jaffrelot, The Pakistan Paradox, 48-49

${ }^{67}$ Muhammad, Writings and Speeches of Syed Ahmad Khan, 266.

${ }^{68}$ Ibid., 160.
} 


\section{The Conceptualization of 'Nation-as-family' in Pakistan-India Relations}

This section sheds light on how the conceptual metaphor of family shaped the relations of both groups in pre-partition period and how they conceptualized themselves as parting members of a family-as-nation after partition in 1947.

In inter-national relations, nation-as-family metaphor is very powerful and is always conceptualized while dealing with other nations. Pandit Jawaharlal Nehru, the first Indian Prime minister had aptly remarked that because of their very close contacts, India and Pakistan cannot be indifferent to each other. They can either be more than friends or become more than enemies. Soon after the creation of Pakistan, Mr. Jinnah, the founding father of Pakistan held a meeting with the US ambassador Paul Alling in Karachi. Jinnah expressed his feelings for India to him that nothing was dearer to him than close relations between India and Pakistan and that he wished for India and Pakistan to have an association similar to that between Canada and the Unites States, which could allow the two neighbours to have largely unguarded borders, shared defence, free trade and freedom of movement to and from. ${ }^{69}$ In fact, Mr. Jinnah had kept his houses in Bombay and Delhi - he had shared his desire of returning to India after retirement with Indian ambassador Sri Prakash. He even continued to pay his Income tax as an Indian and managed his stock business there through his manager. In his presidential address to Pakistan's first Constituent Assembly on 11 August 1947, Jinnah showed his optimism by saying that the mighty revolution of Partition had resolved India's constitutional problem of one religious community being in majority and another being a minority and that it was now time for cooperation and forgetting the past. ${ }^{70}$ While being emotionally so much attached to India, however, Mr. Jinnah was sceptic about Indian's complex of superiority when he was asked if

\footnotetext{
${ }^{69}$ Dennis Kux, Disenchanted Allies: The United States and Pakistan, 1947-2000 (Baltimore: Johns Hopkins University Press, 2001), 25. Telegram from Embassy Karachi to State Department, March 22, 1948.

${ }^{70}$ Muhammad Ali Jinnah and Jamil-ud-Din Ahmad, Speeches and Writings of Mr. Jinnah (Vol. II) (Lahore: Sh. Muhammad Ashraf Publishers, 1947), 399-404.
} 
India and Pakistan would use peaceful means to resolve any of their disputes, Mr. Jinnah replied, "Yes, provided the Indian government will shed the superiority complex and will deal with Pakistan on an equal footing and fully appreciate the realities. ${ }^{71}$

All India Congress always viewed Jinnah's two-nations doctrine as false and pledged in its resolution while approving Partition plan that: "after the subsiding of present passions, India's problems would be viewed in their proper perspective and the false doctrine of nations will be discredited and discarded by all. ${ }^{72}$ Moreover, it was an unexpected catastrophe and incalculable violence that accompanied Partition confining both countries into water-tight borders. Both the newly born states had to bear an enormous influx of refugees who were full of grievances and anger towards the other state. Although the founding fathers of India such as Gandhi and Jawaharlal Nehru gave statements to set Pakistani fear of dismemberment aside but it did not pacify the atmosphere of high anxiety on both sides. In 1948, Nehru categorically stated that India had no desire of disintegrating Pakistan: "if today by any chance I were offered the reunion of India and Pakistan, I would decline it for obvious reasons. I do not want to carry the burden of Pakistan's great problems. I have enough of my own". ${ }^{73}$ Gandhi, using the metaphor of family, as he always did, requested the Indians that Pakistan be treated like members of a family who had moved out of a joint family to their own home; Pakistanis needed to be won over, not cut off further from their estranged clan. ${ }^{74}$ Ironically, such statements only added to Pakistani paranoia and mistrust towards India as the parting family members always strive to build their distinct identity in contrast to the previous one. First Pakistani Prime minister Liaqat

\footnotetext{
${ }^{71}$ Rizwan Ahmed (ed.), Sayings of Quaid e Azam M. A. Jinnah (Karachi: Pakistan Movement Research Center, 1970), 81.

${ }^{72}$ Khalid Bin Sayeed, Pakistan: The Formative Phase (Ann Arbor: University of Michigan Press, 1960), 175.

${ }^{73}$ Jawaharlal Nehru's speech at Aligarh University, 24 January 1948. Jawaharlal Nehru Speeches. Sept 1946May 1949, Vol. 1 (New Delhi: Press Publication Division, Ministry of Information and Broadcasting), 337-39. ${ }^{74}$ Husain Haqqani, India vs Pakistan: Why Can't we Just be Friends? (New Delhi: Juggernaut Books, 2016), 11.
} 
Ali Khan had said that "the truth of the matter is that the leaders of India have not accepted Pakistan and keep on devising methods of undoing it. But Pakistan is an unalterable fact" ${ }^{75}$

Hindu-Muslim grouping in the subcontinent can be explained by assuming them as, groups that were once one and may have split centuries before, with each of resulting groups remaining largely endogamous, thus producing opposed but physically similar population. Ethnic groups that are regarded as fundamentally different from or opposed to each other have, drawn on the same gene pool. In part, the group disparity reflects recognition of individual group membership by other than birth criteria - conversion, intermarriage, passing, as well as the merger of subgroups. ${ }^{76}$ All these characteristics can be seen as the reason for rise in Muslim population over centuries in the Indian subcontinent.

There is a confusion regarding ascribing ethnic separators to Hindu-Muslim conflict in the Subcontinent. This puzzle can be less confusing if we regard ethnic affiliations as being located along a continuum of ways in which people organize and categorize themselves along kinship patterns. The Hindus and Muslims had shared a common fate for more than a millennium. Religion and geography did not divide them. Hindus lived under Muslims' rule. Muslims lived under Maratha and Sikh rulers. Later after the mid eighteenth century, both were subject to the British Raj. Both rebelled against their British masters in 1857 but denied. Religion was never a big issue. Many Hindus converted to Islam but kept their caste identity intact. In many settings, conquerors destroy all or a part of religion of the indigenous people. This leads to adopting of beliefs and practices of the conquerors, especially when the success of the conquerors is associated with the superior strength of their gods. The religion thus formed in this process is often neither precisely that of the conqueror nor the traditional one of the

\footnotetext{
${ }^{75}$ Mujtaba Razvi, The Frontiers of Pakistan: A Study of Frontier Problems in Pakistan's Foreign Policy (Karachi: National Publishing House, 1971), 51.

${ }^{76}$ Horowitz, Ethnic groups in conflict, 53.
} 
conquered. It is new one using elements of both, created through a process known as syncretism, or the conscious adaptation of an alien idea or practice in terms of some indigenous counterpart. ${ }^{77}$

The existing Caste-system (Varna) helped indigenous people not only to absorb Muslims but also many different religions, as another caste. Moreover, the local kinship structures and common lineages soothed the development process of a grand Hindustani family, Qaum or Biraderi comprising people from different religions. It is not to say at all that people had no religious differences at all but the beauty of this society remained in the absence of an acute communalism among different religious groups. Despite adopting Islam as religion, local people never abandoned their caste identity. Put it simply, the Indian Subcontinent had evolved into an Indian family, Qaum or Biradari with several extended family groups (on religion base). The partition of India was, therefore, literally taken as 'Batwara' of the Indian subcontinent by the local people.

It is an admitted fact that Biradari system (kinship groups) had stronger bonds for people than religion. People never abandoned their Biradari and honour attached to their descendant lineages. People in sub-continent still feel more pride in their lineage than religion. Often the Muslim Rajputs are heard saying that they converted to Islam just a few hundred years ago but they are Rajputs since the known world history. Rajputs, Jats, and Brahmins carried on with their lineage identity even after changing their religions. Although, the supposedly egalitarian concept of Islam about treating all human beings equally attracted local people from lower castes but these people never achieved the highest status within Muslims. The converts tried to abandon their previous lineage identities but in vain. This lineage bond is still the strongest in the sub-continent. One can find Muslim Jats in Pakistan and Hindu Jats in India; especially in

\footnotetext{
${ }^{77}$ Barnett Homer Garner, Innovation: the basis of cultural change (New York: McGraw Hill, 1953), 49-54.
} 
the Punjab region found in both states. Sir Denzil Charles Ibbetson, a Lieutenant Governor of British Punjab in early twentieth century also noted that most of the agricultural castes of the Punjab identified among Hindus, Sikhs, and Muslims shared the same kinship lineages. ${ }^{78}$

Based upon their lineage ties, the emotional attachment between Hindus and Muslims can be gauged from the following story narrated by an interviewee to Ishtiaq Ahmad who has compiled first-hand accounts of people who themselves observed Indian partition. The interview of Rao Abdur Rashid, ex-Inspector General of Police, Punjab-Pakistan reveals the emotional climate of British India just before the cataclysmic event of 1947 . He narrates:

\begin{abstract}
"Our hamlet Kalanaur (now in India) was the stronghold of Muslim Rajputs. They were very strict Rajputs. They preserved the purity of their blood with great care. In village, 10,000 Muslim constituted more than half of its population. We had blood relations with Hindu Rajputs. We belonged to the same Biradari. In the Panchayats (village councils), Muslim and Hindu Rajputs would sit together and make decisions and give verdicts. Before the Pakistan movement started there was no distinction of Hindu or Muslim, the distinction was between Rajput and non-Rajputs. The Rajputs (Hindus and Muslims) considered themselves superior and were also because they own all land ..... However, as the Pakistan movement gained momentum, Hindu-Muslim relations also developed. In one village, Hindu Rajput boys set a mosque on fire. Their elders were deeply saddened. A Panchayat was called in which both Hindu and Muslim Rajputs participated. The Hindu Rajputs begged forgiveness and offered to repair the mosque. So, again the fraternal spirit was restored. However, a Hindu Rajput said in an emotional manner: 'we are the descendants of the same mother. A revolution took place and we took different paths (that is some converted to Islam while others remained Hindus). Now again another revolution is about to take place. Why don't we become one again? Why do you want to leave your blood relatives and go to another country? The appeal was made with great sincerity". ${ }^{79}$
\end{abstract}

Therefore, we can categorize Pakistani-Punjabis as a "split-ethnic group", who had to part ways from his Hindu/Sikh Punjabi brothers to join his Muslim brothers having different ethnicities such as Baloch, Sindhi or Pashtun. The demography of Punjab province was entirely changed after partition with the migration of over ten million people across the infamous Radcliffe line now dividing them in two parts. It was not only a geographical division but also a psychological

\footnotetext{
${ }^{78}$ Denzil Ibbetson, Punjab castes: Races, castes and the tribes of the people of Punjab (New Delhi: Cosmo Publications, 1981, first published 1916).

${ }^{79}$ Ishtiaq Ahmed, The Punjab Bloodied, Partitioned and Cleansed: Unravelling the 1947 tragedy through secret British reports and first-person accounts (Oxford University Press, 2011), 45.
} 
divide between the people who were not sure till the last that such division could occur. Such a forced migration on the eve of Indian Partition is sometimes equated with the migration of European nations after the second world war, where Poles, Hungarians and the Czechs expelled the Soviets from the areas of their control while the Germans were meted out with the same treatment at the hands of Allied nations. The argument is raised that why India and Pakistan are still obsessed with each other while these European nations have learned to live peacefully. In fact, in Europe, the movement was largely in one direction: Germans being forcibly moved towards the truncated Germany; however, in Punjab, people moved in both directions between East and West Punjab. Eminent historians such as Penderel Moon and Mark Tully state that: "Between August 1947 and March 1948 about four and half million Hindus and Sikhs migrated from West Pakistan to India and about six million Muslims moved in the reverse direction. A great part of this massive migration took place within only three months after the partition" ${ }^{80}$

Local Punjabis still use the indigenous terms for both the Punjabs such as Charhda Punjab (The Rising one) for Indian East-Punjab and Lehnda Punjab (The Falling one) for Pakistani West-Punjab. Similar was the case with Bengalis, as Muslim Bengalis had to side with Pakistanis by abandoning their Hindu ethnic brothers in the West-Bengal in India. As said, the ethnic groups exhibit the characteristics of a large family, these split-ethnic groups then exhibited the sentimental behaviour similar to that of divided family members. For this reason, the conflictual and cooperative patterns observed in their own family settings were also transposed to their intergroup, interethnic, and interstate relations. ${ }^{81}$

\footnotetext{
${ }^{80}$ Penderel Moon and Mark Tully, Divide and Quit: An eye Witness Account of the Partition of India (California University Press), 268.

${ }^{81}$ See for a similar debate: Horowitz, Ethnic groups in conflict, 59.
} 


\section{Conclusion}

The interstate relations are nothing but relations between individuals on wider scale. States are hierarchically organized group of people - full of emotions, and, national interest is the highest level of social as well as psychological aggregation. The states cannot ignore popular sentiments regarding aggression, and, oftentimes, formulate their policies based upon its society members" "spirit" and "psyche". 82 The state actions mostly depend upon "conceptualization" of the situation by the individual actors responsible for decision-making. To reason about such difficult and abstract concepts involving state-craft, people as well as policy makers recall to more easy and concrete concepts e.g. indigenous family models. On that account, the obsessive Pakistan-India relations are heavily influenced by the emotions associated to their indigenous family dynamics.

Pakistan presumes herself as the 'wronged' party after Batwara. Therefore, unconsciously, Pakistan exhibits the characteristics of 'weak' family member' in this family-dyad; always determined to right the wrong done to him. Therefore, there are two conflicting emotions: one is to undermine the former partner and second is all about fearing to be assimilated back by the powerful family member. The fear to be merged back in Indian territory was an outcome of the statements given by prominent Indian leaders soon after the partition. Sardar Patel, the then Deputy Prime Minister of India publicly doubted Pakistan's prospects for survival as a separate country, insisting that sooner than later both countries shall again be united. He never hesitated to remind his countrymen that the creation of Pakistan had cut the important limbs of mother India. ${ }^{83}$ Such statements from the Indian side created an atmosphere of perpetual fear fro

\footnotetext{
${ }^{82}$ Richard Ned Lebow, A cultural theory of international relations (Cambridge University Press, 2008).

${ }^{83}$ Ramchandra Guha, India After Gandhi: The History of the World's Largest Democracy (New York: HarperCollins, 2007).
} 
Pakistanis but there remained certain nostalgic feelings attached to their relations that if both groups could live as one unit.

Although, the explanation of India-Pakistan rivalry in terms of a "sibling-rivalry" or "stepbrother-rivalry" is not new, yet it remained an unexplored subject through theorizing their emotions. It is to add here that conceptualizing other religions in terms of Jati or Biradari is not a new concept in the Indian Subcontinent. The ancient caste system (varnas) dates back to the bronze age and the Aryan invasion in the India Subcontinent resulted in granting the local Dravidians with the lowest status in Varnas i.e. Dalit or Harijan. The invading Aryans classified themselves into four major types on the basis of labour of division: the pious class (Brahimins), the warrior class (Ksatriya), the merchant class (Vaisya), and the servant class (Sudra). Later on, local people always used to absorb incoming people including the Muslims in shape of a loose varna or Jati (Zat or Biradari). Such a continuous assimilation process had bound them into a sort of fictive kinship structure and the fracture in this structure at the time of Partition engaged them in a rivalry flooded with deep seated emotions. To sum up here, a few verses from an Indian poetess and novelist Amrita Pritam's famous poem “Ode to Waris Shah" are reproduced here. Legend has it that Amrita wrote this poem after witnessing the bloodshed of Partition, on her migratory train ride from Pakistan to India in 1947. She was deeply moved by witnessing the people cutting each other's throats who were like a family a few days ago. ${ }^{84}$

Today, I call to you Waris Shah

Answer me from your grave!

And, then, in that book of love of yours

Move on to a new page.

Once cried a daughter of the Punjab

And you composed that narrative of pain

Today countless daughters are wailing

\footnotetext{
${ }^{84}$ Amrita Pritam's poem is her call to the legendary Punjabi Poet Waris Shah (1722-1798) whose "Heer" is considered as the Bible of Punjabi Poetry.
} 
And say to you, 'O Waris Shah'.

Rise, you the soother of the hurt

Wake up, and look at your Punjab

Today the corpses are scattered everywhere

And blood runs deep in the Chenab

Someone has poured in five rivers

A venom very potent

And with that deadly concoct

Has watered all our fields. ${ }^{85}$

${ }^{85}$ Translated from the Punjabi language by Nirupama Dutt, Retrieved at: https://thewire.in/books/amrita-pritamcentenary 